\title{
POWDER, POMP, POWER: TOWARD A TyPOlOgY AND GeNEALOGY OF EFFEMINACIES
}

\author{
Peter Hennen \\ University of Minnesota
}

\begin{abstract}
An analysis of some of the varying historical and cross-cultural meanings of effeminacy and their relationship to hegemonic masculinity provides aunique perspectiveon the social construction of thesex/gendersystem cumrentlyoperating in most industrialized societies of the West. In this paper I present a brief review of the historical uses of effeminacy in Europeand the US and develop a five point typology. Mysurvey reveals a plethora of meanings, linking effeminacy alternately with deficient citizenship, a general lack of sexual restraint, excessize heterosexual behavior, exclusive connection with passive bomosexual activity, and finally as an incorrigible proposition that utilizes a naturalistic narrative to link it with homosexual orientation regardless of sexual role. I then employ the typologyintroduced heretoexpand andaugment an argument advanced by Randolph Trumbach to explain theemergence of thestrong cultural link between effeminacy and homosexuality during the $18^{\text {b }}$ centumy.
\end{abstract}

While effeminacy as a cultural concept has been a popular topic among scholars working in history and cultural studies (Sinfield 1994; Trumbach 1977, 1989, 1991, 1998; Bray 1982; Dowling 1993; Erber 1996), among sociologists it has not attracted the attention it deserves. This is unfortunate, as a given society's concept and deployment of effeminacy reveals not only a great deal about the prevailing sex/ gender system (Rubin 1975) ${ }^{1}$, but also yields some important clues as to the dynamics of gender relations within it. My essay is an effort to address this gap in the literature. I begin by looking at some problems of definition with respect to effeminacy. I then introduce a typology of effeminacies that reveals the widely varying historical uses of effeminacy, while also tracing its protean relationship with 
homosexuality. I then revisit a popular explanation for the "marriage" of effeminacy and homosexuality, applying my typology to enhance this explanation.

Problems of Definition: In attempting to devise any meaningful definition of effeminacy, the first issue to be addressed is the misogyny inherent in the term itself. A typical dictionary definition (Webster's Unabridged, 1994) makes it clear that effeminacy is a quality "of a man" who is considered "soft or delicate to an unmanly degree in traits, tastes, habits, etc.;" he is "womanish, characterized by unmanly softness, delicacy," and "self-indulgence."

What is startling here is how little this definition actually reveals. Each of the attributes included in this definition could easily be recast in a positive light ("soft" becomes "sensitive and understanding;" "delicacy" becomes "refinement;" "unmanly traits, tastes and habits" indicate the cultured man of good breeding; "self-indulgence" becomes something like "taking care of yourself"). The critical component of this definition seems to be "womanish," along with the fact that the term is used almost exclusively as a pejorative, and in most contemporary usage strongly suggests homosexuality. Effeminacy, far from implying that a person actually is a woman, signals the fact that a man is "woman-like." Thus the tension between the "reality" of biological sex and the prescribed gender performance is transformed into a personal failing. The fact that this charge is, in the majority of cases in which it is deployed, extraordinarily effective in bringing about the desired change in behavior is just one more indication of what psychologist Robert Brannon terms "the relentless repudiation of the feminine" (1976). As such, I believe it provides a unique perspective from which to analyze the sex/gender system of a given society. More specifically, an analysis of the historical uses of effeminacy can be seen as an indicator of a society's assumptions and attitudes toward women. My focus in this paper is on the varying relationships between effeminacy and hegemonic masculinity (Connell 1987, 1995), i.e., how effeminacy is used to distribute power among men (rather than between men and women) with particular emphasis on its association with homosexuality. Thus, although I do not elaborate on this connection here, I hope that my analysis of some of the historical connections between effeminacy and male homosexuality will identify areas where an investigation of the historical changes in the valuation and empowerment of women might be productive.

In an effort to revise the above definition for the purposes of this essay, a brief review of the historical meanings of effeminacy is in order. In The History of Sexuality, Volume 2 Michel Foucault observes that today "no one would be tempted to label as effeminate a man whose love for women leads to immoderation" (85). However, in ancient Greece men who indulged themselves "immoderately" (either in same or in opposite sex relations) were considered effeminate. This is because the virtue of "moderation" was understood as an inherently masculine trait. According to the ancient Greeks "immoderation derives from a passivity that relates to femininity. To be immoderate was to be in a state of nonresistance with regard to the force of pleasures, and in a position of weakness and submission" (84). Thus, "the dividing line between a virile man and an effeminate man did not coincide with our opposition between hetero- and homosexuality; nor was it confined to the opposition between active and passive homosexuality" (85). The objects of normative sexual desire for adult male Greek citizens ranged from women to boys, slaves (male or female), and non-citizens (male or female). As long as the samesex relations of the adult male citizen occurred with these partners assuming the passive role in any form of intercourse, and as long as the activity was considered "moderate," there was little stigmatization attached to the behavior and the charge of effeminacy simply did not apply. On the other hand, for adult male citizens of ancient Greece this equation between effeminacy and immoderation was of monumental importance with respect to their participation in the public life of the polis. The effeminate was understood as one who had allowed himself, through immoderate sexual activity of virtually any kind, to be distracted from his public duties. 
In The Wilde Century: Effeminacy, Oscar Wilde and the Queer Moment, author Alan Sinfield provides what amounts to an extended history of effeminacy in Western Europe. His major claim is that the connection between effeminacy and homosexuality, advanced as necessary and natural by much of our contemporary culture, is in fact a fairly recent (and socially constructed) phenomena. He cites dozens of examples from European literature of the $17^{\text {th }}, 18^{\text {th }}$ and $19^{\text {th }}$ centuries to illustrate his point. His research reveals that in fact, the very meaning of the word "effeminate" has changed dramatically in the past three centuries. Originally the word indicated an overabundance of feminine sentimentality and emotion. The object of the effeminate man's affection could be either male or female; this had essentially no bearing on his effeminacy. The critical feature was the fact that he was "woman like" in his emotional attachment. Thus, during the $18^{\text {th }}$ century men were sometimes warned to limit their contact with women lest it make them "effeminate." Certain stock characters appearing in European plays written during this period (e.g., the fop, the dandy, the beau) were readily understood by audiences as both heterosexual and effeminate.

According to Trumbach (1989), by the dawn of the $18^{\text {th }}$ century in England the fop, the dandy and the beau were already coming to be replaced by the "molly," an effeminate male presumed to be interested exclusively in other (masculine) men. Drawing on a range of crosscultural evidence, Trumbach argues that roles such as the molly appear in societies as a kind of "bridge" between binary sex roles in societies where those roles are in the process of moving toward similarity. Trumbach attributes the emergence of the molly in England to certain broad-based structural changes that were taking place with respect to marriage and the family, and to a growing recognition that these changes were in some appreciable way moving British society in the direction of gender equity. Thus the molly served the interests of hegemonic masculinity in that he clearly demonstrated the distinction between those men who were quite literally "becoming women," and those whose masculinity remained untainted.
Sinfield takes a differing approach and argues that the sensational series of trials that put Oscar Wilde's homosexual affairs on public display in England functioned as a kind of historical catalyst that forever cemented the connection between effeminacy and male homosexuality in the public's mind. Unlike Trumbach, he argues that before the trials the kind of "decadence" displayed by Wilde would have been more likely interpreted as evidence of heterosexual licentiousness than homosexuality. Wilde's effeminacy allowed for an understanding of homosexual behavior that left the sex/gender system unchallenged. Although it might be stigmatized and publicly condemned, a "womanish" man's desire for another man served to bolster Victorian assumptions about the necessary and "natural" connections between sex, gender and sexual object choice.

In "Chicano Men" Tomas Almaguer argues that although stigma accompanies homosexual practices in Latin culture, it does not equally adhere to both partners. It is primarily the anal-passive individual (the cochón or pasivo) who is stigmatized for playing the subservient, feminine role. He cites Lancaster (113) who observes that the insertive partner (the activo or machista) typically "is not stigmatized at all and, moreover, no clear category exists in the popular language to classify him. For all intents and purposes, he is just a normal male." In fact, the active partner in a homosexual encounter often gains status among his peers in precisely the same way that one derives status from seducing many women:

... Consider for a moment the meaning associated with the passive homosexual in Nicaragua, the cochón. The term is derived from the word colchón or mattress, implying that one man gets on top of another as one would a mattress, and thereby symbolically affirms the former's superior masculine power and male status over the other, who is feminized and indeed objectified (112).

In Manbood in America, author Michael Kimmel remarks on the political uses of effeminacy in the days leading up to the American Revolution. The aristocratic world of Great Britain was understood as effete, 
impotent and soft in comparison to the rugged individualism of the evolving American consciousness. "American men faced a choice between effeminacy and manliness, between aristocracy and republicanism" (19). In later years effeminacy was enlisted to assuage white men's anxieties centered around race and class, as in the "effeminate progeny of mixed races, half Indian, half Negro, sprinkled with white blood" (92). Effeminacy became something of a fashion statement during the early part of the $20^{\text {th }}$ century, in fact it was all the rage during the "pansy craze" in New York City during the 1920's. Ironically, the "pansy craze" was fueled by Prohibition (originally designed to control morally suspect forms of entertainment), which allowed for the expansion of a sexual underworld in New York City that was closely associated with illegal speakeasies. The upper crust flocked to Times Square to see all manner of "gay" entertainments featuring flamboyant, effeminate (and presumably homosexual) men in various clubs and theaters (Chauncey, 305-6). After a subsequent crackdown on such entertainment in the early 1930's, many otherwise "conventionally gendered" gay men continued to advertise themselves sexually to other men by adopting an aggressively effeminate persona in public. Thus an ascendant public perception that linked effeminacy with homosexuality was immediately exploited for practical purposes by gay men themselves.

Cold war America saw one of the most effective political deployments of effeminacy with McCarthyism's portrait of the homosexual as "security risk" (Corber 1997). This equation revived the classical Greek notion of the effeminate as failed citizen, with at least one important change. Here the logic of hegemonic masculinity confidently assumed that the link between effeminacy and homosexuality was both "natural" and necessary, a situation that continued until the years immediately following the Stonewall rebellion of 1969. In his study of gay masculinity, Martin P. Levine reveals that an authentic challenge to the sex/gender system was launched by the more radical wing of the gay movement in the years immediately. following Stonewall, but its appeal was short-lived:
Gay activists formulated radically different images of the postcloset homosexual. Some gay liberationists viewed this man as a politicized hippie who eschewed traditional manliness, conventional aspirations, and established institutions. He avoided the quick sex associated with the sexual marketplace and formed instead lasting relationships. And he wore "gender fuck" attire that mixed masculine and feminine (beards and dresses). Gay reformists, by contrast, viewed the postcloset homosexual as a "butch' rebel who had sex with "anyone, any way, any time." He actively participated in the sexual marketplace, "cruising" and "tricking' in gay bars, bathhouses, and pornographic bookstores. The liberationist image gathered few converts as most gay men found gender fuck too radical. They opted instead for the reformist image of the postcloset homosexual (Levine, 28).

This flight from effeminacy is supported in this excerpt from one of Levine's field interviews. Here an aging member of the gay community in New York (c. 1975) casts a jaundiced glance backward as he assesses some of the changes in gay culture during the early 70 s:

\begin{abstract}
"Honey, when you have been around as long as I have, you get to know a lot of men. Over the last few years, I have watched many of these girls change as the times changed. A couple of years ago, they had puny bodies, lisping voices, and elegant clothes. At parties or Tea Dances, they came in dresses, swooning over Garbo and Davis. Now, they've 'butched up,' giving up limp wrists and mincing gaits for bulging muscles and manly handshakes, giving up fancy clothes and posh pubs for faded jeans and raunchy discos" (55-6).
\end{abstract}

From the preceding historical survey we see that effeminacy has alternately been understood as 1.) a passive disposition toward pleasure and self discipline that was perceived as "womanish," 2.) A moral failure resulting from a kind of "contamination" by the feminine, 3.) A willingness toward objectification in sex, 4.) A means of resolving tensions within a particular sex/gender narrative, and finally, 5.) A way of presenting oneself to the world, through either a style of dress or movement (or both) that is understood as "womanly." Although they do not correspond exactly, I use these observations to develop a five point typology of effeminacy in the next section. I 
conclude this section by offering the following (provisional) definition of effeminacy: Effeminacy is a n bistorically varying concept deployed primarily as a means of stabilizing a given society's concept of masculinity and controlling the conduct of its men, based upon a repudiation of the feminine that recognizes it as a "present absence." Thus, effeminacy can be seen as a disciplinary development within hegemonic masculinity; a mechanism which, despite its widely varying cultural and historical manifestations provides a remarkably effective means of policing the boundaries of acceptably masculine behavior. Furthermore, I mean to suggest here that the concept of effeminacy encodes some of the central paradoxes of masculinity as it currently operates in most industrialized cultures. "Real men" are never feminine, yet "real men" must remain ever vigilant against the feminine. Masculinity is an essential and natural consequence of biological sex, yet it must be carefully taught and learned. Authentic masculinity implies freedom and control, yet anything marked as feminine is strictly proscribed.

A Typology of Effeminacies: The typology I present here is not meant to identify new types of individuals. Unlike Richard von KrafftEbing, who in his notorious catalogue of sexual perversions (Psychopathia Sexualis) invented a host of new demons for sexologists to investigate, I have no desire to attach these effeminacies to fixed identities. Thus my work here is not meant to identify "types of people," but rather, on Becker's advice (1998) as a description of a socially intelligible types of activities that certain people occasionally engage in (45). Furthermore, in my reading across a fairly wide variety of sources, I have been repeatedly surprised by my ability to identify these forms. The distinctions I make here have emerged from the data itself, and I am confident that they have been tacitly operating as social types for some time. Since naming is a source of power in itself, this typology may, in some small way, serve to counter hegemonic masculinity wherever concepts of effeminacy are deployed. Finally, although I have made an attempt to construct an exhaustive typology (given the protean nature of effeminacy, this is probably best considered a provisional attempt), I do not in any way see the various forms of effeminacy as mutually exclusive. A great deal of overlap between these types should be expected when considering any specific historical case. In fact, the argument might be made that they are, in some sense, cumulative forms (i.e., each type builds upon or is in some sense dependent upon, the prior form). While I do not pursue that argument here, I have ordered my presentation in a way that is conducive to this view.

Political: Here effeminacy represents a lack of fitness for citizenship and the demands of active involvement in state activities. This type predominates in ancient Greece (Dover, 1989). Where this view of effeminacy prevails, it may or may not be associated with same-sex desires, or it may pertain only to specific practices regardless of sexual object. For example, in Ancient Greece, same-sex desire and behavior is neither proscribed nor feminized; rather any indicator of submission among male citizens (including but by no means limited to passive anal sexuality) is marked as effeminate and condemned as evidence of poor citizenship. On this reading effeminacy represents a significant danger to the political health of the polis. As with nonsexual forms of passive behavior, the male citizen's active involvement in affairs of state is threatened by adopting a passive sexual role. ${ }^{3}$

Moral: On this view, effeminacy is understood as a form of moral weakness, specifically a "softness" with respect to pleasure. The effeminate man is prey to his passions; for food and creature comforts as well as sexual gratification. An inability to reign in these passions is understood as "womanlike" and provides a sharp commentary on the debased status of women with respect to morality. This form of effeminacy is decidedly not associated with exclusive homosexuality. Rather, it assumes that all men must remain vigilant against the temptations of excessive sexual activity in general. As sexual objects, this form of effeminacy makes no distinctions between women, men, animals or the effeminate's own body. Lack of self-control (rather than sexual object choice) is the critical factor, and this version of effeminacy assumes that all men are equally vulnerable to temptation from women and men. The "homosexual" as a separate species is not acknowledged. During the Renaissance, this type of effeminacy 
is more closely associated with "debauchery," and in certain periods is articulated in terms of class (particularly with respect to the "debauchery" of the aristocracy). ${ }^{+}$

Cosmetic: This form of effeminacy emphasizes outward appearance as an indicator of the "womanly" man. Specifically, the use of women's clothing, jewelry and make-up is understood as signaling effeminacy. Thus, this type of effeminacy is employed in categorizing a wide range of men who alter their appearance in violation of conventional norms of masculine dress and grooming. Transvestism, the most extreme case of cosmetic effeminacy, was understood as a vice in its own right during the Renaissance, entirely independent of same-sex desire. It was not until the $18^{\text {th }}$ century that this form became closely associated with homosexuality.

Somatic: This form reads the body itself (rather than the accoutrements of dress and make-up) as evidence of effeminacy. It can be further divided into kinesthetic effeminacy, wherein a man is judged by prevailing standards as either moving or using his voice "like a woman," and anatomical effeminacy, wherein a man's genitals, build, or facial features are interpreted as feminine or less than masculine. The relationship between somatic effeminacy and homosexuality is complex. While in some deployments this relationship may be heavily implied, somatic effeminacy is only occasionally regarded as conclusive proof of same sex interest among boys and men. More often it extends and underscores the importance of repudiating the feminine as it may be expressed by (or read into) the movement and appearance of the male body. In contemporary societies then, its primary purpose seems to be surveillance and discipline (Foucault 1995).

Appended: This is a new form of effeminacy that has emerged only recently. It is an ironic deployment of cosmetic effeminacy to underscore masculinity, and, indirectly, heterosexuality. It is a flamboyant and playful display of what I would call "straight camp" that invokes a theatrical display of the "feminine side" of men whose masculinity is beyond question. As Sinfield remarks, "A real man can do whatever he chooses; after all” (28). This form is particularly interesting because it begins to address one of the paradoxes of masculinity outlined above; authentic masculinity implies freedom and control, yet all that is marked as feminine is strictly forbidden. However, it is important to acknowledge that appended effeminacy is reserved for the very few men whose masculinity is beyond reproach. Perhaps the most familiar examples of this form are Dennis Rodman and Jesse Ventura. ${ }^{5}$ This form of effeminacy is an "appendage" in two senses: it is appended to an unassailably masculine persona, and it thereby acts to emphasize and enhance that masculinity in much the same way that the padding of an "appended" codpiece did in an earlier era.

The Marriage of Effeminacy and Homosexuality: I turn now to an application of this typology to a specific historical puzzle. The preceding examples raise a number of interesting questions. When and where was the dominant meaning of effeminacy transformed to indicate homosexuality? Why did this transformation occur when and where it did? I believe that Randolph Trumbach (1977, 1991, 1998) provides the most comprehensive account in response to these questions with his study of the sodomitical cultures of Enlightenment England.

While several scholars have placed the "wedding date" for effeminacy and homosexuality sometime in the middle to latter half of the $19^{\text {th }}$ century (Sinfield 1994, Dowling 1993, Erber 1996), Trumbach traces the relationship back much further. He finds evidence as early as the $12^{\text {th }}$ century that "whenever homosexual behavior surfaced at the royal courts ... it was accompanied by what contemporaries viewed as markedly effeminate behavior" $(1977,11)$. Here is the first instance in which distinctions between types of effeminacy may be of use. I would suggest that aristocratic effeminacy is best understood as a subset of what I have identified above as moral effeminacy, with one important caveat. The immorality of this particular form of aristocratic behavior is attributed to it from outside of elite circles, 
and it is understood as an aristocratic indulgence unto itself, quite separable in the popular imagination from the aristocratic indulgence in same-sex passion. Aristocrats themselves undoubtedly held a different view of their effeminate behaviors (although to the extent that they were aware of the negative moral judgments of their social inferiors, they may have relished the "naughtiness" of effeminacy). First of all, despite the fact that both effeminacy and sodomy were associated with the aristocracy, they were not necessarily correlated with each other. As Sinfield points out, "The aristocrat was expected to be effeminate, so same-sex passion was not foregrounded by his manner" (41). He goes on to cite an example that suggests that among the elite, effeminate behavior (including transvestism) may have been understood as "good clean fun," part of the privilege accorded those with high social standing, appreciated even by those aristocrats who explicitly scorned same-sex activity (42). From the perspective of the aristocrats engaged in it then, effeminacy may perhaps be best described as a kind of carnival. In the terms I've introduced here it was more likely understood as something closer to cosmetic, or perhaps even somatic effeminacy than moral effeminacy.

This of course, provides us with only part of the picture. Nevertheless, Trumbach makes it clear that the association between homosexuality and effeminacy was not completely secured in the popular imagination until the $18^{\text {th }}$ century. He explains this as a reaction to the confluence of two distinct historical trends. The first trend is the development of a distinctly homosexual sub-culture at least partially reliant upon secret meeting places throughout London, and the popular descriptions of these places that emphasized the effeminate behavior of their patrons. Beginning in 1699 and again in 1707 and 1726, the London authorities began raiding "molly houses" in various parts of the city (Bray, 1982). ${ }^{6}$ These houses were scattered across an area north of the Thames, providing clandestine meeting places for men with same sex interests. They were also the site of flamboyant displays of transvestism and effeminacy. An agent who had visited a molly house in advance of a raid left this account as part of a court transcript:
On Wednesday the $17^{\text {th }}$ November last I went to the prisoner's house in Beech Lane, and there I found a company of men fiddling and dancing and singing bawdy songs, kissing and using their hands in a very unseemly manner... In a large room there we found one a-fiddling and eight more a-dancing country dances.. Then they sat in one another's lap, talked bawdy, and practiced a great many indecencies. There was a door in the great room, which opened into a little room, where there was a bed, an into this little room several of the company went ... (cited in Bray, 82).

Elsewhere in the transcript we find a vivid description of a drag ball at the molly house in the Old Bailey:

\begin{abstract}
.. . they had no sooner entered but the Marshal was complemented by the company with the titles of Madam and Ladyship. The man asking the occasion of these uncommon devoirs, the Marshal said it was a familiar language peculiar to the house. The man was not long there before he was more surprised than at first. The men calling one another 'my dear' and hugging, kissing, and tickling each other as if they were a mixture of wanton males and females, and assuming effeminate voices and airs; some telling others that they ought to be whipped for not coming to school more frequently . . . Some were completely rigged in gowns, petticoats, headcloths, fine laced shoes, furbelowed scarves, and masks; some had riding hoods; some were dressed like milkmaids, other like shepherdesses with green hats, waistcoats, and petticoats; and others had their faces patched and painted and wore very extensive hoop petticoats, which had been very lately introduced (cited in Bray, 87).
\end{abstract}

These descriptions are interesting, both for what is said and what is not. To a $21^{\text {st }}$ century audience, perhaps most salient are the descriptions of cosmetic effeminacy ("fine laced shoes, furbelowed scarves, and masks; extensive hoop petticoats, which had been very lately introduced") and somatic effeminacy ("using their hands in a very unseemly manner; assuming effeminate voices and airs"). This may be because they conform so well to our already formed understanding of the stereotypically effeminate homosexual. But Sinfield warns against such a reading: 
How rash it might be to assimilate these men to modern patterns is suggested by reports, dating from 1709 and 1813, that mollies mimicked not just marriage but childbearing - with a midwife, nurse, and doll to represent the child. It is very hard to imagine 'childbearing' scenes in twentieth-century queer or gay culture; there are breaks as well as continuities in the transmission of the molly-house model (39). ${ }^{\text {? }}$

What is not mentioned in the preceding description, and what surely went without saying at the time (given the fact that these descriptions are taken from criminal court proceedings), is that all of this activity would undoubtedly have evoked a powerful and extremely negative set of moral associations from its contemporary audience.

The existence of the London molly houses shows that a sub-culture of men with same-sex interests existed as early as the late $17^{\text {th }}$ century, and Trumbach notes that "descriptions of the sub-culture which were intended for the general public always emphasized its effeminacy" $(1977,17)$. However, there seems to be a wide discrepancy between the interpretations encouraged by such popular accounts and the understandings of the mollies themselves. The key to understanding this discrepancy may lie in an appreciation of the particular type of effeminacy celebrated in the molly houses. Trumbach notes that the London mollies were primarily drawn from the middle and lower classes; he further notes that popular opinion held (erroneously) that molly houses were frequented primarily by aristocrats. Thus, the flamboyant displays of effeminacy in the London molly houses may easily have been understood by their lower and middle class patrons as little more than a playful and theatrical form of social climbing, one perhaps designed to assuage misgivings these men may have had about the legitimacy of their desires and the community they were forming:

To people of the lower class, a noble - powdered, pomaded, refined - was both elegant and effeminate; but that bothered no one as long as the mode of attire remained faithful to the specific superior social condition which its wearer represented. If someone lower on the social scale assumed this costume... not only did he betray his social condition, but in addition, his effeminacy, by losing its accepted association with elegance and the upper class, became an indication of the wearer's real effeminacy (Rey 189, emphasis mine)

Thus, using the typology introduced here, we might say that while the mollies were engaged in an enthusiastic embrace and celebration of the "lighter" side of cosmetic and perhaps somatic effeminacies - as a theatrical pretense to a higher social standing than they actually enjoyed - the general public interpreted the whole affair in starkly moralistic terms. It is important to remember that although public concern with the existence of the molly houses waxed and waned during the $18^{\text {th }}$ century, when the crackdowns came they were swift and terrible. The raids (particularly the one in 1726, involving some 20 houses) resulted in executions, imprisonment and suicides (Bray $81-114){ }^{8}$

The second trend that helped to secure the relationship between effeminacy and homosexuality, according to Trumbach, is the reaction against the "sentimental movement" that increasingly came to bear on heterosexual gender relations during the $18^{\text {th }}$ century. According to its tenets, married men and women were encouraged to form close bonds that emphasized the intimacy of the marital relationship and introduced an egalitarian element not present in earlier conceptions of marriage. "But it is apparent," remarks Trumbach "that a married man who went to whores did so in part because he wished to limit the degree of intimacy with his wife" $(1991,203)$. It seems that the gendered sexuality of many $18^{\text {th }}$ century men was still effectively governed by close associations between women, intimacy, and effeminacy. Furthermore, with the vitriolic reaction to effeminacy in London's molly houses, these men may have had an additional reason for patronizing prostitutes:

The man without a wife who went to whores did so for a different but related reason. He was determined to show that his sexual interest was exclusively in women and that he was not an effeminate passive sodomite. Though it may not seem so at first, it is very likely that this fear of male passivity and the new sodomitical role that it produced in the early Enlightenment 
was also a consequence of the anxieties induced by the new ideal of closer, intimate, more nearly equal relations with women ... The sodomite and the prostitute guaranteed that ordinary men would never be transformed into women as a result of the intimacy or the passivity that might be produced by more nearly equal relations between men and women (203)

"What changes, then," remarks Sinfield, "is that male and female become polar opposites" (45). This is in line with the transition among natural scientists investigating the human body, from a onesex model that emphasized sameness to the two-sex biological model that prevails today (Lacquer 1990). ${ }^{9}$ It also marks the beginning of a new understanding of gender wherein masculinity and femininity are interpreted as the essential, natural developments of two entirely different sexes. In this new understanding, effeminacy quickly comes to be deployed as a means of policing the boundaries between effeminate men and "real" men, between men and women, and between prescribed homosocial relationships and proscribed homosexual relationships. This continues to be critically important, especially in the case of men who submit to the passive role in anal intercourse. The revised sex/gender system demands that he be feminized. Otherwise, a man who "takes his sex like a woman" might accidentally be treated socially as a "real" man. Such a man is perfectly positioned to refute the naturalistic narrative that claims that sex is naturally determinative of sexuality, and leads inevitably to an eternal and unchanging masculinity or femininity (Butler 1990).

$$
\begin{gathered}
* * * * * * \\
\text { Forgaymen, effeminatetraitsare: } \\
\text { Natural (834) } 32 \% \\
\text { A learned behavior (796) } 31 \% \\
\text { Not Sure or Depends(923) } 36 \% \\
\text { - Survey results posted on straightacting.com }
\end{gathered}
$$

In this concluding section I would like to briefly examine what has become of effeminacy in light of gay liberation and poststructuralist challenges to gender essentialism. It would be inaccurate to say that such challenges have not had their effects. Gender today is much more likely to be understood as something people do (Butler 1990, West and Zimmerman 1987) rather than something people are. Yet even a cursory glance at the contemporary cultural scene yields evidence that effeminacy's disciplinary power is far from exhausted. On the contrary, it may be generating anxieties in previously unimaginable domains.

In 1982, a novelty book entitled Real Men Don't Eat Quiche became an instant best-seller. The book provides a tongue-in-cheek guide to help heterosexual men secure their masculine identity and avoid looking like effeminate "quiche eaters." In addition to quizzes and cartoons, the book is filled with prescriptions and proscriptions, many in the form of lists (real men vs. quiche-eaters). For example: "Three things you won't find in a real man's pocket: 1 . lip balm 2. breath freshener 3. opera tickets" (42). That the book was enormously successful is perhaps not surprising; its publication seemed perfectly timed to exploit men's post-feminist gender anxieties. What is a bit surprising is that 1982 also saw the publication of another guide to masculinity, this one entitled The Butch Manual, which targeted an exclusively gay male readership. The differences between the two books are not nearly as striking as their similarities. Consider this example from The Butch Manual: "Things tricks will not find in butch's bathroom: a soft plastic toilet seat, designer towels with a matching bath mat, a shower curtain ...” (76).

Twenty years later this spirited revival of masculinity continues, with the parallels in the gay and straight male communities more apparent than ever. In 1999 The Man Show debuted on a cable comedy channel and has enjoyed high ratings ever since. Billed as the "anti-Oprah," the show's humor proceeds from an unapologetic recuperation and boisterous celebration of "real" masculinity - political correctness be damned. On The Man Show real men are relentlessly heterosexual but denigrate and objectify women (gleefully - each episode ends with images of young buxom women jumping on trampolines). Male 
homosexuality is figured on the show as inherently effeminate, and hosts Adam Carolla and Jimmy Kimmel spend much of their time defining the "real man" against the affectations and histrionics of the effeminate homosexual. Curiously, at about the same time, a website targeting gay men (StraightActing.com) debuted, billing itself as "masculinely politically incorrect" and dedicated to disparaging gay effeminacy. The emergence of StraightActing.com can be seen as the crest of a wave of anti-effeminacy sentiment that began in reaction to the brief period of post-Stonewall gender experimentation in the gay community. ${ }^{10}$ Since that time, gay men have been steadily re-investing in masculinity. Personal ads placed by American gay men now routinely include phrases such as "straight acting and appearing," "no fems," and "masculine GM seeks same." StraightActing.com sponsors an ongoing series of "unscientific" polls which are nevertheless instructive for what they reveal about many gay men's continuing concern with the stigma of effeminacy. The survey items also encode traces of the effeminacies I have introduced in this paper: "Which effeminate behavior bothers you more - lisp, waving hands, limp wrists [somatic], tweezed eyebrows [cosmetic]?" "Which makes a guy the most masculine looking? [cosmetic]" "Does having a pride sticker on your car make you more effeminate? [this item suggests a rather disturbing inversion of political effeminacy, whereby active political engagement is feminized]" "Do guys become more effeminate when they fall in love? [a hearkening back to the strand of moral effeminacy that equated it with the "softness" of the finer romantic feelings]"11

Finally, poststructuralist challenges to the stability of sex/gender have had a curious effect on the disciplining of female bodies. A certain intolerance for the female who is "too femmy" seems to be slowly making its way into heteronormative culture. In a recent teen film entitled She's All That, two girls pass each other outside their high school. "I've seen you in gym class - you run like a girl," says the first. "I am a girl," replies the second, defensively. Whether or not this nascent trend develops into something more substantial is unclear at this writing; what is clear is that the example cited demonstrates the use of effeminacy as a tool to discipline bodies sexed female, in a way that directly references history of male (somatic) effeminacy. Interestingly, there is not much evidence supporting the existence of a similar pattern among queer subjects engaged in what Judith Halberstam has dubbed "female masculinity" (1998). ${ }^{12}$ This raises a number of interesting questions. Insofar as we may assume that female masculinity is performed on bodies that were (or are) sexed female and to some extent socialized as feminine, we may now be in a position to speak of gendered experiences of masculinity. It seems safe to say that various queer subjects have destabilized gender to the point where its performativity is becoming increasingly apparent, but the fact that effeminacy is not deployed to discipline female masculinity suggests that, as the products of distinctly different social processes, men and women may experience the performance of masculinity on their bodies in radically different ways.

An analysis of effeminacy's historical role allows us to see more clearly the primacy of gender in the sex/gender system. Whether we are considering the gendered sexuality of the male citizens of Ancient Greece, who might enjoy a wide range of sexual partners and were free to engage in a variety of sexual practices provided their participation involved manly domination; or the reluctance of the post-Stonewall American gays to reject conventional notions of masculinity in their pursuit of Eros; or the gendered anxieties of the $18^{\text {th }}$ century men who patronized prostitutes as a way of distancing themselves from the feminine (manifested either through the threat of excessive intimacy with their wives, or through the haunting figure of the passive, effeminate sodomite), we once again find important evidence of gender's fundamental power to order social life. I have also introduced a typology of effeminacies that sociologists of gender may find useful in their ongoing efforts to trace the complexities and changes in the various ways genitals, genders and sexualities are understood and interpreted. Although a more extended application is not possible here, I hope I have provided some clues as to the usefulness of such a typology. 


\section{References}

Almaguer, Tomas. 1991. "Chicano Men: A Cartography of Homosexual Identity and Behavior" Differences 3,2: 75-100.

Aristotle. 1988. The Politics. Cambridge: Cambridge University Press.

Bech, Henning. 1995. "Sexuality, Gender and Sociology." Acta Sociologica. 38:187-192.

Brannon, Robert. 1976. “The Male Sex Role: Our Culture's Blueprint of Manhood, and What it's Done for Us Lately" pp. 1-48 in The Forty-Nine Percent Majority: The Male Sex Role. Deborah S. David and Robert Brannon (eds.) Reading, MA: Adddison Wesley.

Bray, Alan. 1982. Homosexuality in Renaissance England. Boston: The Gay Men's Press.

Butler,Judith. 1990. Gender Trouble New York: Routledge.

Butler, Judith. 1993. Bodies That Matter. New York: Routledge.

Chauncey, George. 1994. Gay New York: Gender, Urban Cultureand the Making of the Gay Male World, 1890-1940. New York: Basic Books.

Connell, R.W. 1987. Gender and Power. Stanford: Stanford University Press.

Connell, R.W. 1995. Masculinities. Berkeley: University of California Press.

Corber, Robert J. 1997. Homosexuality in Cold War America. Durham: Duke University Press.

Dover, K.J. 1989 (1978). Greek Homosexuality. Cambridge: Harvard University Press.

Dowling, Linda. 1993. "Esthetes and Effeminati." Raritan. 12,3: 52-68.

Erber, Nancy. 1996. "The French Trials of Oscar Wilde." Journal of the History of Sexuality. 6,4: 549-588.

Feirstein, Bruce. 1982. Real Men Don't Eat Quiche. New York: Pocket Books. Foucault, Michel. 1995 (1977). Discipline and Punish: The Birth of the Prison New York: Vintage Books.

Foucault, Michel. 1990 (1978). The History of Sexuality, Volume 1 New York: Vintage Books.

Foucault, Michel. 1990 (1985). The History of Sexuality, Volume 2 New York: Vintage Books.

Greenberg, David F. 1988. The Construction of Homosexuality. Chicago: The University of Chicago Press.

Halberstam, Judith. 1998. Female Masculinity. Durham: Duke University Press.

Henley, Clark. The Butch Manual. 1982. New York: The Sea Horse Press. Kimmel, Michael. 1996. Manhood in America: A Cultural History. New York:
Krafft-Ebing, Richard von. 1893. Psychopathia Sexualis, with Especial Reference to Contrary Sexual Instinct: A Medico-Legal Study. Translated by Gilbert Chaddock. Philadelphia: F.A.Davis.

Lancaster, Roger N. 1987. "Subject Honor and Object Shame: The Construction of Male Homosexuality and Stigma in Nicaragua" Ethnology 27,2: 111-25.

Levine, Martin P. 1998. Gay Macho: The Life and Death of the Homosexual Clone. New York: New York University Press.

Lloyd, Moya. 1999. "Performativity, Parody, Politics." Theory, Culture and Society. 16:2; 195-213.

Munoz, Josè. 1996. "Famous and Dandy like B. 'n' Andy: Race, Pop and Basuiat." In Pop Out: Queer Warhol Durham, NC: Duke University Press.

Newman, Leslea (ed). 1995. The Femme Mystique. Boston: Alyson Publications.

Rey, Michael. 1988. "Parisian Homosexuals Create a Lifestyle, 1700-1850" in R.P.

Maccubbin, ed., 'Tis Nature's Fault. Cambridge: Cambridge University Press.

Rubin, Gayle. 1975. "The Traffic in Women: Notes on the 'Political Economy' of Sex.” Pp. 157-212 In Rayna R. Reiter, ed., Toward an Antbropology of Women. New York: Monthly Review Press.

Sinfield, Alan. 1994. The Wilde Century: Effeminacy, Oscar Wilde and the Queer Moment. New York: Columbia University Press.

Trumbach, Randolph. 1977. "London's Sodomites: Homosexual Behavior and Western Culture in the 18th Century." Journal of Social History. 11,1: 1-33.

Trumbach, Randolph. 1989. "The Birth of the Queen: Sodomy and the Emergence of Gender Equality in Modern Culture" in Hidden From History: Reclaiming the Gay and Lesbian Past. Duberman, Martin B., Martha Vicinus and George Chauncey Jr. (eds.) New York: New American Library.

Trumbach, Randolph. 1991. "Sex, Gender, and Sexual Identity in Modern Culture: Male Sodomy and Female Prostitution in Enlightenment London." Journal of the History of Sexuality. 2,2: 186-203.

Trumbach, Randolph. 1998. Sex and the Gender Revolution, Volume 1. Chicago: University of Chicago Press.

West, Candace and Don H. Zimmerman. 1987. "Doing Gender" Gender and Society 1:125-151

Weston, Kath. 1996. Render Me, Gender Me. New York: Columbia University Press. 
Notes

'Rubin defines "sex/gender system" as "the set of arrangements by which a society transforms biological sexuality into products of human activity, and in which these transformed sexual needs are satisfied." My perspective in this essay assumes that hegemonic masculinity plays a critical role in structuring this set of arrangements.

${ }^{2}$ Clearly, my working definition is derived from Foucauldian notions of discipline and normalization. Insofar as I have undertaken this study to identify possible areas of resistance and re-reading in the historical record my objectives are in line with various modes of queer theorizing. However I am not so queer here as to apply the notion of effemincacy to the performative practice of masculinity (Butler 1990) on bodies sexed female (see Halberstam, 1998). Such practices undoubtedly have a rich and complex history, but I would argue that conscious, reflexive identifications of such performative practices as masculine (as opposed to butch) are very recent. Thus as a disciplinary device deployed in the service of a normalized masculinity, my history of effeminacies focuses on bodies sexed male. I briefly take up the topic of female masculinity in my conclusion. For an analysis of butch/femme relationships within contemporary lesbian cultures see Weston (1996); for a more specific focus on femme identity see the collection of essays edited by Newman (1995).

${ }^{3}$ As stated, these categories are not proposed as mutually exclusive. One area of substantial overlap exists between moral and political effeminacies. Perhaps the most prominent example of this type of convergence can be found in Aristotle's disccusion of the various regimes of power in the Politics. The forms of government preferred by Aristotle are (in descending order of preference) monarchy, aristocracy and polity (or constitutional republic). However, each of these forms may devolve respectively into tyranny, oligarchy and democracy if the moral character of the ruler(s) is not sound.

${ }^{4}$ Greenberg (1988) reports complaints of what I would term moral effeminacy from $11^{\text {th }}$ and $12^{\text {th }}$ century clerics: "The young men of the royal court had begun to wear long hair and women's clothing, and adopted effeminate mannerisms; it was this the monks found offensive". Ordericus Vitalis, a cleric in England at the time of the Norman conquest, "deplored the court of William Rufus, son of the Conqueror, where 'the effeminate predominated everywhere and revelled without restraint ..." (292). Greenberg notes that such passages condemn homosexuality only incidentally; "their deepest preoccupation is with men dressing and acting like women" (293). Much later, Kimmel (1996) presents evidence that Christ himself had to be rescued from charges of effeminacy as part of the "Muscular Christianity" movement of the late $19^{\text {th }}$ and early $20^{\text {th }}$ centuries in England and the United States. The goal of the Muscular Christians was to transform Jesus from a "thin reedy man with long bony fingers and a lean face with soft, doelike eyes and a beatific countenance," into a "brawny caprneter, whose manly reslove challenged the idolotars, kicked the money changers out of the temple, and confronted the most powerful imperium ever assembled" (176-77).

${ }^{5}$ While Dennis Rodman's penchant for make-up and dresses is wellknown, the gender-bending behavior of the current governor of Minnesota, Jesse Ventura, is perhaps less familiar. As a former professional wrestler, Jesse "The Body" Ventura often appeared in the ring wearing a feather boa. After being sworn in as governor he appeared at his inauguration ball wearing his trademark boa and sequined glasses.

${ }^{6}$ As Bray explains, the molly house raids were sponsored in London by the Societies for the Reformation of Manners, "a crusading religious organization which played an important role in prosecuting sodomites, prostitutes and sabbath-breakers" (82). As to the specific animus that led to the raids and the extent of punishment meted out to molly house patrons, Bray explains that this was not a matter of a change in the legal standing of such behavior, but rather in its increasing visibility: "There was now a continuing culture to be fixed on and an extension of the area in which homosexuality could be expressed and therefore recognised; clothes, gestures, language, particular buildings and particular public places - all could be identified as having specifically homosexual connotations... it was this that brought upon it the persecution which for so long had been often no more than an unrealised potential. Its visibility was its bane" (92).

${ }^{7}$ It strikes me that this quaint historical example may serve to clarify some of Butler's ideas on the materiality of the body (1993). Extending the notion of performativity from its more familiar association with drag to childbearing serves to illustrate Butler's point that the body that is undeniably "there" at moments like childbirth is also co-constructed by performative practices. As Henning Bech remarks in his review of Butler's Bodies That Matter, "In this way, the 'material' i.e. the allegedly non-constructed sex and body, is inescapably co-constructed by the discursive; discourses establish a 'domain of intelligibility,' a framework for what can at all be spoken of and conceived as the sex and the body" (188). From this perspective, the molly house birthing dramas can be seen as highlighting performative aspects of even the most "material" of bodily experiences. 
${ }^{8}$ Thus it would seem that in terms of advancing less restrictive understandings of gender and masculinity, the effeminate practices within the molly houses did little more than move an outraged "general public" toward a renewed investment in normative masculinity. For a recent critique of drag and gender parody (a la Judith Butler) as a transgressive political strategy see Lloyd (1999).

${ }^{9}$ Laqueur demostrates that scientists moved from viewing the male and female bodies as essentially the same (with the female form being a "less developed" form of the male) to one which emphasized the radical differences in their sexed bodies and dispositions.

${ }^{10} \mathrm{In}$ addition to the evidence provided earlier in this paper, there is this vigorous defense of gender experimentation from Carl Wittman's 1969 Gay Manifesto: "There is a tendency among 'homophile' groups to deplore gays who play visible roles - the queens and the nellies. As liberated gays, we must take a clear stand. 1.) Gays who stand out have become our first martyrs. They came out and withstood disapproval before the rest of us did. 2.) If they have suffered from being open, it is straight society whom we must indict, not the queen" (cired in Miller 1995: 385).

${ }^{11}$ Lest I be seen as a hopeless curmudgeon, I would like to indicate here that I am "in on the joke." I am fully aware that the books, TV show and website mentioned are proposed as entertainment and thus "not to be taken seriously." I am also aware that under conditions of postmodernity, a plethora of resistant (even contradictory) readings are facilitated by these texts. I am less concerned here with the variety of readings enabled by this material than I am with the fact that its manifestly misogynistic focus exists to be subverted in the first place. I would also argue that it is precisely in its function as entertainment that this material most effectively defines the feminine and sustains its denigration.

${ }^{12}$ Citing Josè Munoz (1996) Halberstam offers a possible explanation for this in terms of an "active disidentification," whereby such subjects adopt "a mode of dealing with dominant ideology, one that neither opts to assimilate with such a structure nor strictly opposes it." Thus female masculinity "disidentifies" with hegemonic forms of masculinity, "which are subsequently recycled into alternative masculinities."
Characterizing Gender and RaCE IN THE 2000 SUMMER OLYMPICS: NBC'S Coverage of Maurice Greene, Michael Johnson, MARion Jones, AND CATHY FREEMAN

\author{
DAVID MAYEDA \\ University of Hawaii at Manoa
}

Media representations of A frican Americans and indigenouspeoples tend to follow stereotypical notions of bothgender and race. Because African American and indigenous peoples are gendered and racialized simultaneously by media forces, this study examines bow the television network, $N B C$, managed portrayals of three (3) celebrated $A$ frican American atbletes and one (1) Aboriginal atblete in Sydney's 2000 Olympic Games. Specifically, the study investigates media descriptions of Maurice Greene, MichaelJohnson, Marion Jones, and Catby Freeman. Findings rezeal that media presentations of A frican American men attempt to moderatet breatening imageryout of sport whilealso promoting nationalism, and (for Greene) amplifying threatening imagery in sport. Both African American and Aboriginal women arefeminized, and political activism carried out by Aboriginal at bletes is heavily mitigated by liberal pursuits of multiculturalism, as well as feminizedcommentary.

\section{INTRODUCTION}

Although very few professional athletes openly express political viewpoints, the Olympic Games have stood as a site where various levels of political protest emerge, the Olympics being one of the few global events which consistently attracts extensive worldly attention (Lapchick, 1996). However, in terms of both gender and race politics, the Olympic Games generally reflect larger societal trends. Women, for instance, were not allowed to compete in Olympic competition 